\title{
Critical Analysis of Pensions Taking into Account Selected Aspects of Financial Literacy
}

\author{
${ }^{1}$ Viktoria Daus, ${ }^{2}$ Philippe Krahnhof, ${ }^{3}$ Alexander Zureck \\ ${ }^{1}$ FOM University of Applied Sciences, \\ 2 Lecturer at FOM University of Applied Sciences, \\ ${ }^{3}$ Professor at FOM University of Applied Sciences
}

\begin{abstract}
General financial education, the so-called financial literacy, plays an essential role in private retirement provisions. A study by the Organization for Economic Cooperation and Development (OECD) in 2015 shows that financial literacy is not prevalent in Germany. The aim of this scientific paper is to underline the importance of financial literacy for private retirement provisions. Due to the falling level of pensions in Germany, investments in private pension are essential. Therefore, a regression analysis is carried out. Academic goal is to analyze if gender, net income and academic degree have an impact on positive financial literacy. In summary it can be said that there is a significant influence of gender. Regarding the strong imbalance in the gender distribution (three quarters are male), the data should be expanded in the future. While net income as well as academic degree both have a certain positive effect, a correlation was only shown for net income. An ideal level of private retirement provisions was not determined in the empirical study. Based on these empirical insights, it is recommended that the federal states should invest in the financial education of their citizens in order to prevent poverty in age
\end{abstract}

Keywords: financial literacy, pension, economic development, gender differences

\section{Introduction}

The consequences of the financial market crisis in 2007 / 2008 had extensive effects on the financial literacy of the population. Since then, people are increasingly moving into compromise situations in which financial decisions have to be made and yet financial problems are to be prevented. Often people get into such situations unconsciously, which ultimately goes hand in hand with a lack of knowledge about financial issues. This combination suggests that financial literacy is generally underrepresented in the German population.

Insufficient financial literacy affects many aspects of daily life. For example, loans or accounts that are too expensive are taken out, bad investment decisions are made or people do not have private provisions made in private retirement provision.

In particular, the risk of poverty in old age has increased in the Federal Republic of Germany in recent years. In many cases, the statutory pension insurance exclusively provides a basic provision.

Consequently, the Federal Government in particular is also interested in a high level of financial literacy in order to reduce the spread of old-age poverty among particularly vulnerable ${ }^{1}$ groups such as people with a migration background and mostly low earners.

\footnotetext{
${ }^{1}$ Vgl. OECD, 2015.

Vgl. Arianti, B. F., The Influence of Financial Literacy, Financial Behavior and Income on Investment Decision, 2018, S. 1.
} 


\section{Alexander Zureck}

The aim is to highlight the importance of retirement provision so that financial risks in old age can be $c^{2}$ overed. To this end, the financial literacy of an individual should be improved and an awar ${ }^{3}$ eness of financial products and services created. Consequently, it should be possible to make investment decisions for one's own retirement provisions independently. In order to use as much time as possible to build up retirement provisions, it is advisable to start at a young age. As a result, pupils and students should already be taught about financial topics.

\section{Empirical Procedure}

As the previous deliberations have shown, this is a very current research topic, which is of great relevance for practice.

The empirical analysis is based on a survey conducted by the isf Institute for Strategic Finance on the topic "Finanzberatung 2019: Bank der Zukunft" in 2019. Research in this field is usually based on the concept of Annamaria Lusardi and Olivia S. Mitchell.

This concept from 2008 is also called "The Big Three". Both academics developed three topics to be included in a survey on financial literacy. The capability to make calculations related to interest rates, understanding of inflation and risk diversification.

In this empirical study, a logistic regression is performed with selected parameters. To determine the socio-demographic characteristics of the participants, the following first question was formulated: "Do a person's gender, net income and academic degree influence the probability of positive financial literacy?". Based on this question the following hypotheses could be derived:

Table 1: Hypotheses without theoretical reference

\begin{tabular}{|l|l|l|}
\hline Hypothesis & Ratio & Initial \\
\hline $\begin{array}{l}\text { With increasing number of men, the higher the } \\
\text { probability that positive financial literacy can be } \\
\text { observed. (H1) }\end{array}$ & Gender & SEX \\
\hline $\begin{array}{l}\text { The higher the net income of an employee, the:Monthly Net Income likely is a positive financial literacy. (H1) } \\
\text { more }\end{array}$ & NGK \\
\hline $\begin{array}{l}\text { The higher a worker's academic degree, the:Academic Degree } \\
\text { greater the likelihood that positive financial } \\
\text { literacy is present. (H1) }\end{array}$ & & \\
\hline
\end{tabular}

The following chart lists all the hypotheses derived from the research questions and which have a theoretical reference. Only selected hypotheses are analyzed below.

Vgl. Reinke, H. J., Finanzbildung als gesamtgesellschaftliche Aufgabe, 2018, S. 12.

Vgl. Dorn, F. et al., Altersvorsorge und gesetzliche Rentenversicherung - nachhaltig aufgestellt?, 2016, S. 44-45

Vgl. Lusardi, A., Mitchell, O., The Economic Importance of Financial Literacy, 2014, S. 10. 


\section{Alexander Zureck}

Critical Analysis of Pensions Taking into Account Selected Aspects of Financial Literacy

Table 2: Derived hypotheses with theoretical reference

\begin{tabular}{|c|c|c|c|}
\hline Theory & Hypothesis & Ratio & Initial \\
\hline \multirow[t]{2}{*}{$\begin{array}{l}\text { Markowitz } \\
\text { Portfolio Theory }\end{array}$} & $\begin{array}{l}\text { The higher the monthly savings rate of an } \\
\text { employee, the more likely he or she is to } \\
\text { have positive financial literacy. }(\mathrm{H} 1)\end{array}$ & $\begin{array}{l}\text { Monthly } \\
\text { Savings }\end{array}$ & SPB \\
\hline & $\begin{array}{l}\text { The higher the contribution to } \\
\text { employee's pension scheme, the more } \\
\text { likely it is that this person has positive } \\
\text { financial literacy. ( } \mathrm{H} 1 \text { ) }\end{array}$ & Pension & AVB \\
\hline $\begin{array}{l}\text { Kahne- } \\
\text { man/Tversky } \\
\text { Prospect } \\
\text { Theory }\end{array}$ & $\begin{array}{l}\text { The more frequently information media are } \\
\text { used for investment decisions on pension } \\
\text { schemes, the more probable is a positive } \\
\text { financial literacy. (H1) }\end{array}$ & Information & INFO \\
\hline $\begin{array}{l}\text { Transaction } \\
\text { Cost Theory }\end{array}$ & $\begin{array}{l}\text { The likelihood that an employee has } \\
\text { positive financial literacy increases as the } \\
\text { use of different types of advice increases. } \\
(\mathrm{H} 1)\end{array}$ & $\begin{array}{l}\text { Types of } \\
\text { Advice } \\
\text { Increases }\end{array}$ & BER \\
\hline
\end{tabular}

Various regression analyses are carried out in the present empirical study. The operative data evaluation is carried out by the statistics software R.

The first implementation section looks at the probability of occurrence of financial literacy under the influence of the demographic characteristics of gender, net income and academic degree. Three logistic regressions are performed for this purpose. The first logistic regression is performed with the independent variable of gender. The functional equation for this can be illustrated as follows:

Figure 1: Model equation logistic regression with variable gender

$$
\pi(\mathbf{F L})=\alpha+\sum_{j=1}^{\mathrm{J}} \boldsymbol{\beta}_{\mathrm{SEX}} * \mathrm{SEX}_{\mathbf{i}}+\mathbf{u}_{\mathrm{i}}
$$

$\begin{array}{ll}\text { with } & \text { FL } \\ \alpha & \text { Financial Literacy, dependent variable } \\ \beta_{\text {SEX }} & \text { Regression constant } \\ \text { SEX }_{\mathrm{i}} & \text { Gender for the participant } \mathrm{i} \\ \mathrm{u}_{\mathrm{i}} & \text { Disrupter } \\ \mathrm{i} & \text { number of participants } \\ \mathrm{J} & \text { Number of independent variables }\end{array}$

Following the construction of this function to analyze the probability of occurrence of financial literacy under the influence of gender, the second regression equation considers the independent variable of monthly net income. 


\section{Alexander Zureck}

Figure 2: Model equation logistic regression with variable monthly net income

$$
\pi(\mathrm{FL})=\alpha+\sum_{\mathrm{j}=1}^{\mathrm{J}} \beta_{\mathrm{NEK}} * \mathrm{NEK}_{\mathrm{i}}+\mathrm{u}_{\mathrm{i}}
$$

$\begin{array}{ll}\text { with } & \text { FL } \\ \alpha & \text { Financial Literacy, dependent variable } \\ \beta_{\text {NEK }} & \text { Regression coefficient of the independent variable NEK } \\ \text { NEK }_{\mathrm{i}} & \text { Net Income for the participant i } \\ \mathrm{u}_{\mathrm{i}} & \text { Disrupter } \\ \mathrm{i} & \text { number of participants } \\ \mathrm{J} & \text { Number of independent variables }\end{array}$

The functional equation for the independent variable of net income provides information on the probability of occurrence of financial literacy under the influence of an employee's monthly net income. The last logistic regression in the area of demographic characteristics refers to the independent variable of the academic degree.

Figure 3: Model equation logistic regression with variable academic degree

$$
\pi(F L)=\alpha+\sum_{j=1}^{J} \beta_{A G} * A G_{i}+u_{i}
$$

$\begin{array}{ll}\text { with } \quad \text { FL } & \text { Financial Literacy, dependent variable } \\ \alpha & \text { Regression constant } \\ \beta_{\mathrm{AG}} & \text { Regression coefficient of the independent variable AG } \\ \mathrm{AG}_{\mathrm{i}} & \text { Academic Degree for the participant } \mathrm{i} \\ \mathrm{u}_{\mathrm{i}} & \text { Disrupter } \\ \mathrm{i} & \text { number of participants } \\ \mathrm{J} & \text { Number of independent variables }\end{array}$

\section{Research Results}

\subsection{Descriptive Statistics}

Using descriptive statistics, the following results were obtained. A total of around 368 people took part in the survey. More than half $(n=244)$ is male. The following chart visualizes the relative frequency of gender, as well as the presence of Financial Literacy.

\begin{tabular}{|c|c|c|c|}
\hline \multirow[b]{2}{*}{ Gender } & \multirow[b]{2}{*}{ Number $\mathrm{n}$} & \multicolumn{2}{|l|}{ Financial Literacy } \\
\hline & & Positive present & Negative / not available \\
\hline Male & 244 & $90,98 \%$ & $9,02 \%$ \\
\hline Female & 117 & $76,07 \%$ & $23,93 \%$ \\
\hline
\end{tabular}

Table 3: Relative frequencies of gender

In direct comparison, significantly more men than women have positive financial literacy. The survey participants are mostly in the age group between 21 and 30 years $(n=238)$. People aged 26 to 30 years in particular have positive financial literacy at just under $92 \%$. However, age is not analyzed further in the empirical evaluation. 


\section{Alexander Zureck \\ Critical Analysis of Pensions Taking into Account Selected Aspects of Financial Literacy}

The statement of the monthly net income is taken into account in the regression analysis with exact values, as the respondents have stated their actual income. In order to classify the sample, it is divided into income brackets. The majority of the participants have a monthly net income between $1.001,00$ and $3.000,00$ EUR $(n=228)$. The group of people with the highest percentage of positive financial literacy receives a monthly net income between $3.001,00$ and 5.000,00 EUR.

Considering the ratio "academic degree", empirical studies have constructed a variable that regards some academic degrees in summary form. The majority of respondents state that they have a Bachelor's degree $(n=118)$. Looking at the relative frequencies, most of the participants with a Bachelor degree $(91.5 \%)$ show positive financial literacy. The least survey participants $(n=7)$ indicated the academic degree of the doctorate. However, all without exception have positive financial literacy. Four participants did not indicate their academic degree.

\section{Discussion}

\subsection{Gender}

The results of the Pseudo- $\mathrm{R}^{\wedge} 2$ statistics determined by the software $\mathrm{R}$ shows a very low value, as visualized in the following chart. This suggests that the explanatory variable "gender" has no significant influence on the model. In addition, values in a range from 0.2 to 0.4 indicate that the regressor can adapt optimally to the model. This property cannot be observed for the present model.

Table 4: Values of the quality measure of the independent variable gender

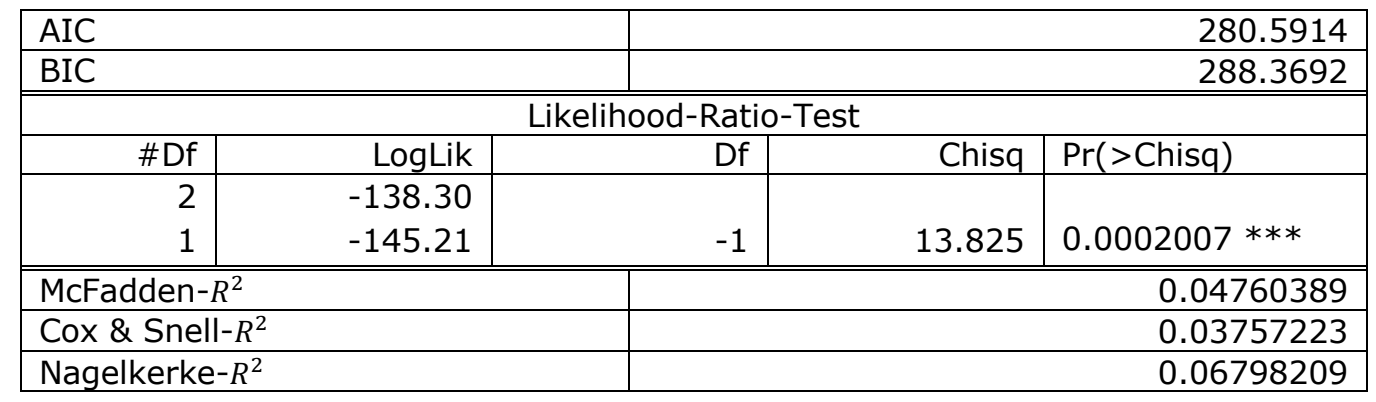

There is a significant influence between gender and the level of financial literacy. The probability of observing positive financial literacy increases with the increasing number of men in the sample. This is underlined by the following chart.

Table 5: Logistic regression for the gender model

\begin{tabular}{|c|c|c|c|c|c|}
\hline & Estimate & Std. Error & z value & $\operatorname{Pr}(>|z|)$ & \\
\hline (Intercept) & 2.3116 & 0.2235 & 10.342 & $<2 \mathrm{e}-16$ & $* * *$ \\
\hline Female & -1.1552 & 0.3113 & -3.711 & 0.000207 & $* * *$ \\
\hline
\end{tabular}

The chance that a woman has positive financial literacy decreases with each additional person in the sample. ${ }^{4}$ With an increasing number of persons, this probability decreases by $217.5 \%$. This finding corresponds with a study by Bucherer-Koenen and Lusardi (2011) that showed that the least financial literacy is found among women.

4 Vgl. Bucher-Koenen, T., Lusardi, A., Financial Literacy and Retirement Planning in Germany, 2011, S. 568-520. 


\section{Alexander Zureck \\ Critical Analysis of Pensions Taking into Account Selected Aspects of Financial Literacy}

\subsection{Net Income}

The second demographic characteristic and thus another independent variable is net income. For the purpose of checking the quality of the model, the values for AIC (248.5219) and BIC (256.0143) should be taken into account for the independent variable net income. In a direct comparison of all demographic characteristics, those for the independent variable of monthly net income are lowest. Accordingly, the information supply for this influencing variable is the highest.

Applying the likelihood ratio test to the present model yields a p-value $<0.05$. Consequently, the result indicates a high significance of monthly net income.

The probability that an employee has positive financial literacy increases with the increase in net income. Provided there is no change in the distribution of net income within the sample, the probability of observing an increase in positive financial literacy remains at just over $0 \%$ with each person more. Certainly, the chance that an employee has positive financial literacy already raises with the increase in monthly net income by 100 euros. The increase is $4.14 \%$. Assuming, that the monthly net income within the distribution raises by 500,00 EUR, the chance of positive financial literacy increases by $22.5 \%$. Wagner already made this finding in his study Financial Education and Financial Literacy by Income and Education Groups. The other way around, people with low incomes also show a low probability of financial literacy.

\subsection{Critical Appraisal of the Research Results}

The results obtained from the study provide a helpful excerpt in the context of the evaluation of the survey "Finanzberatung 2019: Bank der Zukunft" on which it is based. In order to improve the representative result of the study, the sample would have to be significantly expanded. The size of the present sample $(n=368)$ made the evaluation of individual thematic complexes of the questionnaire partially only possible to a limited extent. For the individual variables of the topic complexes, in some cases no influence could be shown among themselves and the result in these cases means no significance. For a further study it would therefore be advisable to extend the sample and moreover, balance the gender distribution, which was not the case here.

\section{Conclusion}

The aim of the investigation was to find out which selected parameters have an impact on the financial literacy of the respondents. Based on this study, conclusions about investment behavior in private pension provision can be drawn.

Empiricism could provide significant academic knowledge. It can be seen that net income and academic degrees have a direct impact on the level of financial literacy, although the academic degree does not develop proportionally. As a result, the state should also offer financial education at an early stage, particularly in the form of schools, from a private pension perspective.

Based on these findings, practical recommendations for action can be derived. Based on the empirical findings, it should be emphasized that people with higher financial literacy are more likely to ${ }^{5}$ invest in private pension provision. Poverty in old age and equal opportunities of different educational levels and origins can only be proactively tackled through adequate financial education

\section{Acknowledgments}

This paper was co-funded by the European Union in the program Erasmus+ in the project (FKZ: 2019-1-CZ01-KA203-0613579), that runs until 08/31/2021.

${ }^{5}$ Vgl. Hastie, T., et al., The Elements of Statistical Learning, 2017, S. 122-125. 


\section{Alexander Zureck}

Critical Analysis of Pensions Taking into Account Selected Aspects of Financial Literacy

\section{References}

- Almenberg, Johan, Säve-Söderbergh, Jenny (akademischer Grad, 2011): Financial Literacy and Retirement Planning in Sweden in: Journal of Pension Economics \& Finance, 2011, Vol. 10 (4), pp. 585-598 Crossref

- Arianti, Baiq Fitri (Financial Literacy, 2018): The Influence of Financial Literacy, Financial Behavior and Income on Investment Decision in: Economics and Accounting Journal, 2018, Vol. 1 (1), pp. 1-10

- Bucher-Koenen, Tabea, Lusardi, Annamaria (Financial Literacy, 2011): Financial Literacy and Retirement Planning in Germany in: Journal of Pension Eco nomics and Finance, 2011, Vol. 10 (4), pp. 565-584 Crossref

- Dorn, Florian, Kauf, Benedikt, Krause, Manuela, Potrafke, Niklas (gesetzliche Rentenversicherung, 2016): Altersvorsorge und Gesetzliche Rentenver- sicherung nachhaltig aufgestellt? in: ifo Schnelldienst, Deutsche Wirtschaftsdatenbank $\mathrm{GmbH}, 2016$, Vol. 69, Iss. 17, pp. 44-48

- Hastie, Trevor, Tibshirani, Robert, Friedman, Jerome (Stichprobe, 2017): The Elements of Statistical Learning Data Mining, Inference, and Prediction, 2017, 2. Auflage, Springer Series in Statistics

- Lusardi, Annamaria, Mitchell, Olivia S. (The Big Three, 2014): The Economic Importance of Financial Literacy: Theory and Evidence in: Journal of Economic Literature, 2014, Vol. 52, Iss. 1, pp. 5-44 Crossref

- OECD (2015): National Strategies for Financial Education. OECD/INFE Policy Handbook, obtained from: http://www.oecd.org/finance/National-Strategies-Financial-EducationPolicy-Handbook.pdf

- Reinke, Hans Joachim (Financial Literacy, 2018): Finanzbildung als gesamtgesellschaftliche Aufgabe in: Zeitschrift für das gesamte Kreditwesen, Jg. 71, pp. 12-13

- Wagner, Jamie (Financial Literacy, 2019): Financial Education and Financial Literacy by Income and Education Groups in: Journal of Financial

Planning, 2019, Vol. 30, Iss. 1, pp. 132-141 Crossref

Counseling and 